\title{
STRATEGIJA REGIONALNEGA RAZVOJA V SLOVENIJI
}

\author{
Ivo PIRY \\ Ministrstvo za gospodarstvo Republike Slovenije, \\ Kotnikova 5, 1000 Ljubljana, Slovenija \\ e-mail: ivo.piry@gov.si
}

\begin{abstract}
Izvleček
Prispevek obravnava vlogo razvojnega načrtovanja na področju regionalnega razvoja, kot ga opredeljuje Strategija regionalnega razvoja Slovenije. Predstavljen je pomen in glavni elementi strategije, kot so vizija, načela in kvantificirani cilji ter institucionalni okvir, ki se neposredno kaže v teritorialni členitvi Slovenije na dvanajst statističnih regij. Predstavljen je Državni razvojni program 2002-2006, ki pomeni operacionalizacijo zastavljenih ciljev.
\end{abstract}

Ključne besede: Slovenija, regionalni razvoj, statistične regije

\section{THE STRATEGY OF REGIONAL DEVELOPMENT IN SLOVENIA}

\begin{abstract}
The article discusses the role of planning in the field of regional development, as it is defined with the Strategy of Regional Development of Slovenia. The importance of the strategy is shown by its elements, vision, principles and quantified targets, and with institutional framework which teritorial dimension is seen in the division of Slovenia into twelve statistical regions. National Development Plan 2002-2006 is presented as operationalisation of the strategy.
\end{abstract}

Key words: Slovenia, regional development, statistical regions 


\section{UVOD}

Proces vključevanja Republike Slovenije v EU je tudi na področje oblikovanja in izvajanja regionalne politike vplival z uveljavitvijo načel evropske strukturne politike, kot so koncentracija, programiranje, partnerstvo, subsidiarnost itd. Novi zakon o spodbujanju skladnega regionalnega razvoja iz leta 1999 dejansko pomeni uzakonitev teh načel, hkrati pa uveljavlja regionalne razvojne programe na ravni statističnih regij kot osnovne razvojne dokumente, za izvajanje celovite razvojne politike. Cilji tako zasnovane regionalne politike so zmanjševanje razvojnega zaostanka Slovenije in slovenskih regij za povprečjem Evropske unije, dvig konkurenčnosti Slovenije in slovenskih regij, doseganje visokega življenjskega standarda in kvalitete življenja ter boljšega zdravja prebivalcev vseh slovenskih regij, pospeševanje razvoja okolju prijaznega gospodarstva ter oblikovanje vseslovenskega gospodarskega razvojnega pola $\mathrm{z}$ dobro prometno povezavo regionalnih središč.

Zavedanje pomena integralnega pristopa in s tem povezovanja ekonomskih, socialnih in prostorskih vsebin razvoja je prisotno $\mathrm{v}$ vseh dokumentih razvojnega načrtovanja v Republiki Sloveniji. V Strategiji gospodarskega razvoja Slovenije - Slovenija v EU - je posebno poglavje namenjeno vprašanjem regionalnega razvoja kot integracije vseh treh vidikov razvoja, $s$ tem je regionalnemu planiranju določena enakovredna vloga kot to velja za države članice EU. Posebej je opredeljena vloga regionalnega planiranja v Strategiji regionalnega razvoja Slovenije, ki temelji na celovitosti reševanja razvojnih vprašanj na celotnem ozemlju države, hkrati pa utemeljuje regionalni pristop s povezovanjem lokalnih skupnosti na ravni funkcionalno povezanih območij-statističnih regij.

\section{VLOGA PROGRAMSKIH DOKUMENTOV}

Slovesu od sistema družbenega planiranja je sledilo dokaj dolgo obdobje, v katerem je bilo celovito planiranje razvoja potisnjeno nekoliko na stranski tir delovanja upravnih struktur. Sprejem prve Strategije gospodarskega razvoja Slovenije v letu 1995 je pomenil najavo novega pristopa na področju načrtovanja gospodarskega in družbenega razvoja, ki je zdaj potekal predvsem v okviru priprave sektorskih strategij in programov na državni ravni (npr. nacionalni program izgradnje avtocest itd.). Pomen načrtovanja se je še okrepil s sprejemom Državnega programa za uveljavitev pravnega reda EU do leta 2002, ki je bil sprejet v letu 1999, ki obravnava vsa področja družbenega sistema. Z vidika razvojnih perspektiv je posebej pomembno 3.poglavje, $v$ katerem je ocenjena sposobnost za prevzem obveznosti polnopravnega članstva na posameznih področjih, od skupnega trga do proračuna, ki obravnava tudi vprašanje socialne in ekonomske kohezije, katera vključuje področja zaposlovanja in socialnih zadev, regionalnega in prostorskega razvoja. Na slednjih dveh področjih je bila prevzeta zaveza za sprejem ustrezne zakonodaje in organiziranosti, ki bo omogočila izvajanje politike socialne in ekonomske kohezije (1). 
V letih 1998 in 1999, torej v času izdelave nove Strategije gospodarskega razvoja Slovenije (dalje SGRS) so se razreševala institucionalna vprašanja, povezana z razvojnim načrtovanjem v Sloveniji(2). SGRS je v slovenski zakonodaji opredeljena kot krovni strateški dokument države iz katerega izhajajo vsi ostali področni razvojni dokumenti in proračunski memorandum. V okviru razprave o Zakonu o javnih financah so bila opredeljena razmerja med SGRS, proračunskim memorandumom in državnim proračunom. Ob Zakonu o spodbujanju skladnega regionalnega razvoja je bilo dorečeno razmerje med regionalno in nacionalno ravnijo razvojnega načrtovanja. Tudi v skupini razvojnih dokumentov, ki jih Slovenija predlaga Evropski uniji, je pomen SGRS še posebej izražen. Makroekonomski scenarij in fiskalni scenarij SGRS sta osnova Predpristopnemu ekonomskemu programu (dalje PEP), investicijski scenarij SGRS pa je osnova državnemu razvojnemu programu. Gre torej za sklop med seboj povezanih dokumentov, katerih notranjo konsistentnost zagotavlja SGRS.

Osnovni cilj SGRS je povečevanje blaginje prebivalcev in prebivalk Slovenije, pri čemer gre za uravnovešeno celoto gospodarske, socialne in okoljske sestavine blaginje. Temu Strategija regionalnega razvoja Slovenije dodaja še cilj spodbujanja skladnega regionalnega razvoja oziroma usmeritev v policentrični razvoj države. Medtem ko je SGRS krovni strateški dokument, ki opredeljuje smernice gospodarskega razvoja Slovenije do leta 2006, je DRP njegov izvedbeni dokument. Osnovna cilja DRP 2001-2006 sta: (i) zmanjšanje gospodarskega zaostanka Slovenije napram povprečju EU in (ii) zaustavitev povečanja razlik med slovenskimi regijami na SKTE-2 ravni.

Državni razvojni program 2001-2006 (dalje DRP) je izvedbeni dokument Strategije gospodarskega razvoja Slovenije, ki jo je vlada sprejela julija 2001 in izhaja iz enakovrednega obravnavanja gospodarske, socialne in okoljske razsežnosti blaginje kot svojega osnovnega cilja. Trajnostni pristop k domačim razvojnim priložnostim pomeni tudi korak k uveljavljanju razvojnih usmeritev Evropske unije (dalje EU). Doseganje cilja socialne in ekonomske kohezije $\mathrm{z}$ razvitimi evropskimi državami v sedanjih razmerah sicer zahteva prednostno zniževanje razvojnega zaostanka na področju gospodarstva, vendar pa doseženo tako, da se ne bodo poslabšali dosežki na področju socialnega in okoljskega razvoja. Poleg gospodarske, socialne, prostorske in okoljske sestavine trajnostnega razvoja državni razvojni program posebej poudarja tudi skladen regionalni razvoj.

Skupni programski dokumenti (Joint Programming Document) INTERREG/Phare CBC 2000-2006 predstavljajo poseben sklop načrtovanja razvoja, ki je že podprt z znanimi sredstvi programa Phare $\mathrm{CBC}$, ki se sicer dokončno določajo na letni ravni, srednjeročno pa so bili okviri postavljeni za obdobje 2000-2002 in 2003-2006. Priprava teh dokumentov je bila usmerjena $\mathrm{v}$ skupno oblikovanje razvojnih odločitev v obmejnem prostoru, skupno določitev razvojnih prioritet ter mehanizmov za izvajanje teh programov. Vsekakor gre za pomemben kakovostni premik k tesnejšemu sodelovanju in predvsem gospodarskemu povezovanju obmejnih območij, spodbujenem z možnostmi, ki jih ponuja povezovanje predpristopnih instrumentov ter spodbud, ki jih EU namenja razvoju območij v okviru Cilja2 ter medregionalnemu povezovanju.

Načela integralnosti, na katerih temelji priprava regionalnih razvojnih programov, uvajajo pristop »od spodaj navzgor«, s katerim se je Slovenija seznanila pri izvajanju 
programov Phare čezmejnega sodelovanja. Metodološka napotila, na podlagi katerih so bili pripravljeni prvi programi ob mejah z Republiko Avstrijo in Republiko Italijo, so zahtevala pripravo regionalnih razvojnih strategij, kot osnovnih dokumentov za nadaljnje postopke izbora projektov v okviru določenih razvojnih prioritet. Posebej uspešno je bilo sodelovanje obmejnih območij ob avstrijsko-slovenski državni meji, kjer je bila delno prilagojena metodologija priprave razvojne strategije uporabljena tudi za slovensko obmejno območje. Izbor razvojnih prioritet je omogočil večje število zrcalnih projektov, predvsem pa nakazal možnosti za skupno načrotvanje razvoja predvsem na področjih kot so turizem, razvoj naravovarstvenih območij, povezovanje malega gospodarstva in področje izobraževanja ter kulturnega sodelovanja.

\section{REGIONALNA RAZVOJNA POLITIKA PO LETU 2000}

Strategijo regionalnega razvoja Slovenije, ki je temeljni strateški dokument s področja regionalnega razvoja, je Vlada Republike Slovenije sprejela v juniju 2001. Dokument je usklajen s Strategijo gospodarskega razvoja Slovenije in opredeljuje cilje regionalnega razvoja ter določa instrumente in politiko za doseganje. To je osnovni strateški dokument slovenske regionalne politike. Temelji na Zakonu o spodbujanju skladnega regionalnega razvoja in njegovih podzakonskih aktih, Beli knjigi o regionalnem razvoju $\mathrm{v}$ Sloveniji ("White Paper on Regional Development in Slovenia", januar 1999), Predhodnem državnem razvojnem programu za obdobje 2000-2002 (november 1999), raziskavi konzorcija slovenskih raziskovalnih inštitutov pod vodstvom Inštituta za ekonomska raziskovanja (»Priprava strokovnih podlag za Strategijo regionalnega razvoja Slovenije«) in Tezah za SRRS iz julija 2000. Priprava SRRS pomeni uresničitev naloge iz Zakona o spodbujanju skladnega regionalnega razvoja in hkrati podrobnejšo usmeritev za nadaljnje izvajanje regionalne politike.

Zakon o spodbujanju skladnega regionalnega razvoja temelji na naslednjih ciljih:

- Spodbujanju uravnoteženega gospodarskega, socialnega in prostorskega razvoja.

- Zmanjševanju razlik v gospodarski razvitosti in življenjskih zmožnosti regij, še posebej podeželskih.

- Preprečevanju nastajanja novih območij z večjimi razvojnimi problemi.

- Ohranjanja poseljenosti na celotnem ozemlju Republike Slovenije (policentrični sistem poselitve).

- Pospeševanje okolju prijaznega razvoja gospodarstva ter varovanja naravnih dobrin, naravne in kulturne dediščine.

Zakon o spodbujanju skladnega regionalnega razvoja predpisuje tudi načela po katerih se naj izvaja regionalna politika v Republiki Sloveniji:

- celovitost izvajanja regionalne strukturne politike na celotnem ozemlju,

- partnersko sodelovanje med državo in v »razvojne regije« povezanimi lokalnimi skupnostmi ter partnerstvo med javnim in zasebnim sektorjem, 
- usklajenost politik in spodbud med posameznimi resorji in spodbud lokalnih skupnosti,

- $\quad$ pristop od spodaj navzgor, torej prenos na višjo raven izvajanja le tisto, kar na nižjem ni smiselno ali možno,

- programsko usmerjanje spodbud v celovite razvojne projekte, ki izhajajo iz regionalnih razvojnih programov.

SRRS je sestavljena iz strateškega in analitičnega dela. V strateškem delu je predstavljena vizija regionalnega razvoja v Sloveniji, ki stremi k trajnostnemu razvoju v najširšem pomenu ob optimalnem izrabljanju vseh potencialov v regiji, pri tem pa ne zmanjšuje virov in možnosti razvoja prihodnjih generacij.

Vizija regionalnega razvoja v Sloveniji so uravnoteženi gospodarski, socialni, kulturni, prostorski in okoljski vidiki razvoja $\mathrm{v}$ vseh slovenskih regijah, kar bo zagotovilo visoko življenjsko raven in kakovost bivalnega okolja vseh prebivalcev Slovenije. Vizija stremi $\mathrm{k}$ trajnostnemu razvoju $\mathrm{v}$ najširšem pomenu, ki optimalno izrablja vse potenciale $\mathrm{v}$ regiji, pri tem pa ne zmanjšuje virov in možnosti razvoja prihodnjih generacij.

Cilji strategije so natančno opredeljeni in zavezujoči, predvsem pa z natančno kvantifikacijo omogočajo spremljanje njihovega uresničevanja:

- Zaustaviti povečevanje razlik $\mathrm{v}$ gospodarski razvitosti in pri življenjskih možnostih med regijami, s poudarkom na celostnem razvoju mest, ki so nosilci regionalnega razvoja $\mathrm{v}$ povezavi s podeželjem.

- Trajnostni razvoj vseh slovenskih regij in preprečevanje nastajanja novih območij z večjimi razvojnimi problemi.

- Ohranjanje minimalne poseljenosti na celotnem ozemlju Republike Slovenije.

- Izboljševanje relativnega položaja slovenskih regij, merjeno v BDP po kupni moči na prebivalca, $v$ primerjavi z obmejnimi regijami v Avstriji in Italiji.

Temeljna strategija bo učinkovito izkoriščanje razvojnih možnosti regij in razpoložljivih finančnih virov (javnih, zasebnih, mednarodnih) namenjenih spodbujanju skladnega regionalnega razvoja ter koordinacija sektorskih in področnih politik. Izkoriščanje lastnih razvojnih virov posameznih regij bo dopolnjevalo aktivno privabljanje domačih in tujih investicij. Slovenska regionalna politika bo temeljila na vzpostavljanju ustreznih pogojev za razvoj, medtem ko bosta regionalna in lokalna pobuda predstavljali gonilno silo razvoja.

Zmanjševanje razvojnega zaostanka Slovenije in slovenskih regij za povprečjem Evropske unije bo dolgotrajen proces, ki ga je možno pospešiti le z dvigom konkurenčnosti Slovenije in slovenskih regij. Dolgoročni cilj je doseganje visokega življenjskega standarda in kvalitete življenja prebivalcev vseh slovenskih regij s pospeševanjem razvoja okolju prijaznega gospodarstva, s poudarkom na celostnem razvoju mest, ki so nosilci regionalnega razvoja $\mathrm{v}$ povezavi s podeželjem. To bo doseženo $\mathrm{z}$ oblikovanjem vseslovenskega gospodarskega razvojnega pola ter $\mathrm{z}$ krepitvijo partnerskih odnosov med državo, lokalnimi skupnostmi in socialnimi partnerji. Z gospodarsko krepitvijo in dobro prometno povezavo regionalnih središč drugega reda ter $\mathrm{z}$ dvigom kategorije najpomem- 
bnejših slovenskih središč (načelo policentričnega razvoja države) ter s pritegnitvijo in križanjem glavnih evropskih prometnih smeri, bodo mesta postala najpomembnejši generatorji razvoja in utrdila svojo vlogo $\mathrm{v}$ evropskem in nacionalnem okviru regionalnih središč.

Potrebno se je zavedati tudi omejitev regionalne politike v Sloveniji. Spodbujanje gospodarskega razvoja ne bo prenešeno na regionalno raven. Do oblikovanja pokrajin bo zato pretežni del spodbujanja skladnega regionalnega razvoja potekal na nacionalni ravni oziroma skozi ukrepe sektorskih in področnih razvojnih politik različnih ministrstev. Dosledno uveljavljanje načela partnerstva pa bo prvi korak in pot do prenosa določenih pristojnosti.

Osnovni dolgoročni cilj SRRS je zmanjševanje razvojnega zaostanka Slovenije in slovenskih regij za povprečjem Evropske unije ob doseganju visokega življenjskega standarda in kvalitete življenja ter boljšega zdravja prebivalcev vseh slovenskih regij. Do leta 2006 so cilji konkretnejši in merljivi: (i) zaustaviti povečevanje razlik v gospodarski razvitosti in življenjskih možnostih med regijami s poudarkom na celostnem razvoju mest, ki so nosilci regionalnega razvoja v povezavi s podeželjem. Ta cilj bomo desegli z najmanj ohranitvijo razlike v kupni moči BDP na prebivalca na ravni statističnih regij na razmerju 1.7:1 med najbolj in najmanj razvito regijo; (ii) trajnostni razvoj vseh slovenskih regij in preprečevanje nastajanja novih območij z večjimi razvojnimi problemi. Ta cilj bo dosežen, če se bo dvignila absolutna raven kupne moči BDP na prebivalca in če se bo zmanjšala registrirana stopnja brezposelnosti v vseh statističnih regijah; (iii) ohranjanje minimalne poseljenosti na celotnem ozemlju Republike Slovenije, tako da neto medregijski selitveni saldo v nobeni statistični regiji ne bo večji od -0.5 prebivalca na 1000 prebivalcev; (iv) izboljševanje relativnega položaja slovenskih regij, merjeno v BDP po kupni moči na prebivalca, v primerjavi z obmejnimi regijami v Avstriji in Italiji. Cilj bo dosežen s hitrejšim razvojem Osrednjeslovenske, Goriške in Obalno-kraške regije od italijanskih obmejnih regij ter dohitevanjem manj razvitih avstrijskih regij; (v) zmanjšati razlike $\mathrm{v}$ zdravju med regijami zaradi slabših razvojnih možnosti (slabše gospodarske in družbene razvitosti) in slabše dostopnosti do zdravstvene službe, kar se bo odrazilo na zmanjševanju razlik v pričakovanem trajanju življenja, splošni ter specifični umrljivosti.

SRRS je določila tudi prednostna območja regionalne politike. Ta bo sicer delovala na celotnem območju države, vendar bo prednost dajala: (i) regijam z nižjo stopnjo razvitosti (glede na višino BDP na prebivalca oz. stopnjo brezposelnosti), (ii) območjem s posebnimi razvojnimi problemi, (iii) obmejnim območjem in (iv) območjem, na katerih živijo madžarska in italijanska narodna ter romska etnična skupnost.

S sprejemom Zakona o spodbujanju skladnega regionalnega razvoja v letu 1999 se je Slovenija opredelila za pomoč regijam in občinam, ki zaostajajo v razvoju. Sprejeti podzakonski akti in Strategija regionalnega razvoja Slovenije so natančno opredelili ta območja. Regionalna politika torej deluje na celotnem območju države, še posebej aktivno pa na prednostnih območjih, kot so:

- regije z najnižjo stopnjo razvitosti (Pomurska, Podravska, Zasavska in Posavska). 
- območja s posebnimi razvojnimi problemi. (i) ekonomsko šibka območja, (ii) območja s strukturnimi problemi in visoko brezposelnostjo in (iii) razvojno omejevana obmejna območja in območja z omejenimi razvojnimi dejavniki. Skupno gre za 129 občin, $57.2 \%$ ozemlja in $48.7 \%$ prebivalstva Slovenije.

- obmejna območja;

- območja na katerih živita madžarska in italijanska narodna skupnost ter romska etnična skupnost;

\section{Institucionalni okvir izvajanja regionalne politike na regionalni ravni}

Pospešitev regionalnega razvoja je odvisna tudi od aktivnosti regionalnih razvojnih agencij, ki so nastale na pobudo in s soglasjem lokalnih skupnosti, večinoma iz že obstoječih institucij (mreža regijskih podjetniških centrov). Regionalne razvojne agencije so namenjene pripravi razvojnih projektov in spodbujanju razvoja v regiji. Občine so jih pooblastile za pripravo regionalnih razvojnih programov oziroma zato, da poganjajo razvoj na območju regije. Živahno razvojno povezovanje občin, ki ga je spodbudila priprava regionalnih razvojnih programov, je še posebej razveseljivo ob dejstvu, da se je $\mathrm{v}$ to aktivnost uspešno vključilo tudi gospodarstvo. Navedeno bo pomagalo aktivirati notranje razvojne potenciale $\mathrm{v}$ regijah na tržno skladen način ter ob pomoči države vodilo v usklajen razvoj po meri posameznih območij. Po zakonu predvidena mreža 12 regionalnih razvojnih agencij v statističnih regijah je oblikovana. Območja delovanja RRA so skladna z območji statističnih regij razen v štirih regijah (glej zgoraj). Štiri RRA so organizirane kot mrežne agencije (na Gorenjskem, Goriškem, v Obalno-kraški regiji in v Podravju), kjer je pogodbeno povezanih več lokalnih razvojnih agencij, ena od njih pa je nosilna.

Osnovi instrument pospeševanja regionalnega razvoja $\mathrm{v}$ regijah in pridobivanja spodbud za te namene ter ena od osnovnih razvojnih nalog regionalnih razvojnih agencij je priprava regionalnega razvojnega programa (v nadaljnjem besedilu: RRP). Sklep o pripravi RRP z navedbo območja priprave in zadolžitvami vključenih institucij sprejme organ upravljanja regionalne razvojne agencije, ki tudi ustanovi programski odbor, ki je odgovoren za programsko usmerjanje RRP. To je temeljni programski in izvedbeni dokument, ki se praviloma pripravi za območje statistične regije in s katerim si regija začrta razvoj v prihodnjih letih. Vsebuje razvojne prednosti regije, finančno ovrednotene programe, podprograme in projekte za posamezna področja regije. Minimalna obvezna vsebina je določena $\mathrm{v}$ navodilu o minimalni obvezni vsebini in metodologiji priprave ter načinu spremljanja in vrednotenja regionalnega razvojnega programa. Priprava RRP je bila sofinancirana s strani države $\mathrm{v}$ vseh dvanajstih regijah, pri čemer je bila upoštevana različna finančna sposobnost regij za financiranje dokumenta. Regijam, ki najbolj zaostajajo $\mathrm{v}$ razvoju je država pokrila $60 \%$ vseh upravičenih stroškov priprave RRP. V okviru posebnega pripravljalnega programa na strukturne sklade EU so bile sofinancirane izobraževalne aktivnosti in nekateri pilotni primeri. 
Postopek priprave RRP se je s sprejemom na občinskih svetih občin zaključil v Koroški, Savinjski in Zasavski regiji že v letu 2001. Do konca leta 2002 so RRP sprejele občine Zasavja, JV Slovenije, Spodnjeposavske, Gorenjske, Goriške in Obalnokraške regije. V letu 2003 so bili izdelani RRP Notranjsko-kraške, Osrednjeslovenske in Pomurske statistične regije. S pripravo RRP so tako zaključile vse statistične regije, razen Podravske, ki pa naj bi pripravo zaključila v teku leta 2003.

\section{PREDNOSTNE RAZVOJNE USMERITVE DO LETA 2006}

$\mathrm{V}$ letu 2000 je Evropska komisija $\mathrm{z}$ namenom pospešitve pred-pristopnega procesa od držav kandidatk zahtevala pripravo Državnega razvojnega programa za obdobje 20012006 (DRP), ki naj bi predstavljal novo osnovo za programiranje pred-pristopne pomoči v okviru programov Phare od vključno leta 2001 dalje. Slovenija je pristopila k izdelavi DRP v juliju 2000, dokument pa je potrdila vladakonec leta 2001. Priprava DRP je potekala sočasno s pripravo državnih proračunov 2001 in 2002/03. Z uvedbo programskega pristopa pri pripravi proračuna in večletnega proračunskega načrtovanja se Slovenija prilagaja sistemom načrtovanja javnofinančnih izdatkov v državah EU s čemer so bili ustvarjeni pogoji za sočasnost in tesno vsebinsko navezavo priprave DRP na postopke priprave državnega proračuna.

Državni razvojni program 2001-2006 pokriva celotno obdobje sedanje finančne perspektive Evropske unije. Prva tri leta se nanašajo na predpristopno obdobje 20012003, druga tri leta pa na obdobje predvidenega članstva Slovenije v EU.

V predpristopnem obdobju dokument predstavlja prilogo Državnega programa RS za prevzem pravnega reda EU programsko podlago za črpanje sredstev različnih oblik predpristopne pomoči, skladno s prioritetami Partnerstva za pristop. Za obdobje polnopravnega članstva pa predstavlja DRP osnovo za pogajanja o finančni alokaciji strukturnih skladov in kohezijskega sklada Republiki Sloveniji.

Priprava državnega razvojnega programa je v Sloveniji prispevala k vzpostavljanju in usposabljanju ustanov, ki so zadolžene za pripravo in izvajanje ekonomske in socialne kohezije na državni in regionalni ravni. S poudarkom na načelu partnerstva je bil s pripravo DRP storjen pomemben korak naprej pri utrjevanju partnerske vloge države $\mathrm{s}$ socialnimi partnerji, regionalnimi partnerji in institucijami civilne družbe. Dobili smo nov instrument, ki integrira razvojne aktivnosti Vlade Republike Slovenije in prispeva k njenem učinkovitejšem delovanju.

\section{Razvojne značilnosti upoštevane v DRP}

Z BDP na prebivalca po kupni moči v višini 16.100 evrov (2000) dosega Slovenija $72 \%$ povprečnega BDP v EU. V obdobju 1995-2000 je Slovenija občutno zmanjšala razvojni zaostanek za državami EU, saj je povprečni bruto domači proizvod na prebivalca po kupni moči narasel s $64 \%$ na $72 \%$ povprečja EU. Kljub temu razvojni zaostanek ostaja 
precejšen, še posebej na tako ključnih razvojnih področjih kot je razvoj človeških virov ter telekomunikacij in informacijske infrastrukture, kar se odraža v nižji produktivnosti gospodarstva. Med regijami v Sloveniji obstajajo precejšnje razlike v gospodarski razvitosti, ki se še povečujejo. Osrednji del države okoli glavnega mesta Ljubljane se razvija bistveno hitreje od preostalega dela. V razvoju najbolj zaostaja jugovzhodni del države.

Geografska lega Slovenije je ugodna zaradi (i) bližine najbolj propulzivnih, hitro razvijajočih se okolij EU; (ii) "ponovnega odpiranja" vzhodne Evrope, kar nova propulzivna gravitacijska središča pomika bliže Sloveniji, in (iii) specifičnega položaja do držav nekdanje Jugoslavije. Geografskostrateški položaj Slovenije omogoča povezovanje na ravni mestnih regijoziroma medregionalno povezovanje, ter sodelovanje $\mathrm{z}$ evropskimi regijami. Problem je slaba povezanost $\mathrm{z}$ modernimi avtocestami in predvsem dotrajanost železniške infrastrukture. Da bi izkoristila prednosti svojega geostrateškega položaja, bo Slovenija še naprej razvijala transportno infrastrukturo tako sama kot tudi v sodelovanju z EU.

V obmejnih pasovih s sosednjimi državami (Avstrija, Hrvaška, Italija, Madžarska) se nahaja več kot polovica slovenskega ozemlja in prebivalstva. Razlike med slovenskimi obmejnimi območji so precejšnje in so večinoma pogojene z razlikami v politični in gospodarski sestavi sosednjih dežel. Vzpostavljanje "schengenskega režima" na meji s Hrvaško prinaša nove ovire $\mathrm{v}$ čezmejno sodelovanje in povečuje zahteve po infrastrukturnem opremljanju obmejnega pasu. To zahteva povečan obseg vlaganj, pri čemer Slovenija koristi predpristopno strukturno pomoč EU. Do vstopa v EU naj bi bila večina investicij, povezanih z uveljavitvijo "schengenskega režima", zaključenih. Tudi po vstopu v EU bo potrebno nadaljevati z vlaganji, ki so namenjena spodbujanju čezmejnega sodelovanja in ustvarjanju pogojev za kvalitetno bivanje in delo ob meji s Hrvaško.

Sosednje države, Italija, Avstrija, Hrvaška in Madžarska, predstavljajo za Slovenijo pomemben regionalni prostor, kamor Slovenija izvaža 30,9\% svojega celotnega izvoza in od koder uvaža 33,0\% svojega celotnega uvoza. Italija je naša druga, Hrvaška tretja in Avstrija četrta najpomembnejša zunanjetrgovinska partnerica. Sosednje države so tudi med najpomembnejšimi investitoricami v Slovenijo - na Avstrijo odpade 45,6 \% celotne vrednosti neposrednih tujih investicij v Slovenijo - ter prejemnicami investicij iz Slovenije - na Hrvaško odpade 45,1\% celotne vrednosti slovenskih neposrednih investicij v tujino (podatki za leto 2000).

\section{Razvojne prioritete DRP}

Slovenija ima jasno razvojno vizijo, ki je na znanju temelječa družba z mednarodno konkurenčno ekonomijo ter trajnostnim, regionalno uravnoteženim razvojem. Razvojni scenarij predvideva, da bo Slovenija $\mathrm{z}$ naložbami $\mathrm{v}$ razvojne prednostne naloge $\mathrm{v}$ obdobju 2001-06 ob koncu obdobja presegla mejo 75\% povprečja EU (15) v BDP na prebivalca po kupni moči. V okviru DRP bo Slovenija v obdobju 2001-06, izvajala aktivnosti za doseganje osrednjih razvojnih ciljev $\mathrm{v}$ okviru naslednjih petih razvojnih prednostnih nalog, ki so razčlenjene $\mathrm{v}$ programe in podprograme, in ki se bodo izvajali v 
Sloveniji in bodo financirani iz zasebnih in javnih sredstev (državnih, občinskih in evropskih):

- Spodbujanje podjetniškega sektorja in konkurenčnost;

- Znanje, razvoj človeških virov in zaposlovanje;

- Informacijska družba, infrastruktura in kakovost bivanja;

- Prestrukturiranje kmetijstva in razvoj podeželja ter

- Spodbujanje skladnega regionalnega razvoja.

Tabela 1: Predvideno financiranje prednostnih nalog DRP s strani EU; obdobje 2004-2006, $v$ milijonih EURO, stalne cene 1999

\begin{tabular}{|l|r|r|}
\hline Programski sklopi & $\begin{array}{r}\text { Vsi odhodki } \\
\text { DRP }^{1}\end{array}$ & $\begin{array}{r}\text { Sofinanciranje } \\
\text { DRP s strani EU }\end{array}$ \\
\hline Skupaj DRP & $7700(100 \%)$ & $2189(100 \%)$ \\
\hline 1. Spodbujanje podjetniškega sektorja in konkurenčnosti & $1206(15.7 \%)$ & $398(18,2 \%)$ \\
\hline 2. Znanje, razvoj človeških virov v in zaposlovanja & $1302(16.9 \%)$ & $490(22.4 \%)$ \\
\hline 3. Ekonomska infrastruktura in kakovost bivanja & $4523(58.7 \%)$ & $932(42.6 \%)$ \\
\hline 4. Prestrukturiranje kmetijstva in razvoj podeželja & $326(4.2 \%)$ & $147(6.7 \%)$ \\
\hline 5. Krepitev skladnega regionalnega razvoja & $318(4.2 \%)$ & $201(9.2 \%)$ \\
\hline 6. Tehnična pomoč & $26(0.3 \%)$ & $22(1.0 \%)$ \\
\hline
\end{tabular}

Vir: Državni razvojni program republike Slovenije - povzetek predloga, Ministrstvo za gospodarstvo, ARR, 2002

\begin{tabular}{|c|l|}
\hline $\begin{array}{l}\text { Razvojna } \\
\text { prednostna naloga }\end{array}$ & KREPITEV SKLADNEGA REGIONALNEGA RAZVOJA \\
\hline Program 1 & Integralni program razvoja mest in podeželja \\
\hline Podprogrami & $\begin{array}{l}\text { Program razvoja javnega prometa; } \\
\text { Prenova in regeneracija mestnih središč ter degradiranih -urbanih } \\
\text { območij. }\end{array}$ \\
\hline Program 2 & $\begin{array}{l}\text { Razvoj kulture in ohranjanje naravne in kulturne dediščine } \\
\text { kot dejavnik razvojnega zaposlovanja na regionalni ravni }\end{array}$ \\
\hline Podprogrami & $\begin{array}{l}\text { Razvoj večnamenskih regionalnih centrov; } \\
\text { Vzdrževanje in upravljanje kulturne dediščine na območjih s posebnimi } \\
\text { razvojnimi problemi; } \\
\text { Podjetništvo v kulturi; } \\
\text { Sonaravni razvoj in vzpostavljanje varovanih območij narave. }\end{array}$ \\
\hline Program 3 & Razvoj regionalne infrastrukture \\
\hline Podprogrami & $\begin{array}{l}\text { Razvoj regionalne komunalne infrastrukture; } \\
\text { Razvoj lokalne prometne infrastrukture. }\end{array}$ \\
\hline Program 4 & $\begin{array}{l}\text { Spodbujanje gospodarskega razvoja narodnostnih manjšin } \\
\text { in etničnih skupnosti }\end{array}$ \\
\hline Podprogrami & $\begin{array}{l}\text { Gospodarska osnova za narodnostne skupnosti; } \\
\text { Gospodarska osnova za Rome. }\end{array}$ \\
\hline
\end{tabular}


Kot primer priprave in vsebine dokumenta podrobneje predstavljamo zadnjo prednostno nalogo - spodbujanje skladnega regionalnega razvoja, z opredelitvijo ključnih programov in podprogramov, na ravni katerih so opredeljeni posamezni ukrepi in aktivnosti.

\section{ZAKLJUČEK}

Pri zasledovanju ciljev zagotavljanja skladnega regionalnega razvoja, ki jih postavlja SRRS izhajamo iz strokovne predpostavke, da je osnova zagotavljanja skladnejšega regionalnega razvoja krepitev gospodarske moči regij in da je slednjo ob upoštevanju procesov gospodarske globalizacije možno doseči, če politika pri spodbujanju razvojnih procesov $\mathrm{v}$ regijah izhaja iz temeljnega strokovnega spoznanja sodobnih analitikov ekonomskih procesov, ki opozarjajo na t.i. lokacijski paradoks. Ta ugotavlja, da bolj kot se gospodarstvo globalizira, bolj je potrebna gospodarska »specializacija posameznih regij«, da bi slednje ohranile oz. povečale svojo konkurenčnost. Brez uveljavljanja slednje ni novih delovnih mest, nasprotno regije, ki ne uvajajo teh procesov nezadržno izgubljajo konkurenčnost $\mathrm{s}$ tem pa tudi delovna mesta. $\mathrm{V}$ kolikor v posamezni regiji ni moč najti ustrezne razvojne moči gospodarskih nosilcev, pa je potrebno vse razvojne napore regije usmeriti v vzpostavljanje pogojev za privabljanje čimvečjega števila potencialnih investitorjev iz drugih regij (držav).

Sodobna razvojna paradigma temelji torej na predpostavki, da mora konkurenčnost posamezne regije izhajati iz specifičnih značilnosti prevladujoče strukture gospodarstva značilne za posamezno regijo. Ker pa $\mathrm{v}$ pogojih naglega tehnološkega razvoja nič ni dokončno, mora biti regija usposobljena za uvajanje procesov stalnega inoviranja. Da pri tem vrsta industrijske panoge ni pomembna, nenazadnje dokazuje konkurečnost sosednjih severno- italijanskih regij, ki so uspešno inovirale tradicionalne industrijske regije.

Model razvoja konkurenčnosti regij, se tako preusmerja od iskanja komparativnih prednosti regij temelječih na zniževanju proizvodnih stroškov, $\mathrm{v}$ iskanje prednosti temelječih na kvalitativnih elementih temelječih na inovacijah in uvajanju novih tehnologij, te pa lahko nastajajo le ob pospešenem povezovanju podjetij, šol, raziskovalnih institutov in nosilcev poslovnih storitev.

\section{Literatura in viri:}

Cappelin, R., 1993: Regional Economic Development, Regionalism and Interegional Cooperation. Paper for the European Summer Institute in Regional Scence, Joensuu, Finland.

Državni razvojni program RS 2001-2006, sprejet na 54. seji Vlade RS, dne, 13. decembra 2001

Kukar, S., 1996: Regionalna politika in čezmejno sodelovanje. V Strategija ekonomskih odnosov s tujino-Slovenija in Evropska unija. Ljubljana: MEOR. 
Plut, D., 1998: Slovenija in sonaravna evropska politika. V Regionalizem v Sloveniji.Uredil Ciril Ribič. Ljubljana: Časopisni zavod Uradni list Republike Slovenije.

Ravbar, M., Piry, I., 2001: Die Erneuerung der Regionalpolitik im Prozess der EU Integration Sloweniens. V: Steinkellner, Maria (ur.).Regionalpolitik und Regionalplanung bei EU - Erweiterung, (Forum Raumplanung, 2). Wien: Öster-reichische Gesellschaft für Raumplanung, 2001, 2, 15-20.

Strategija regionalnega razvoja RS, sprejeta na 38. seji Vlade RS, dne, 26. julija 2001

Urad Republike Slovenije za makroekonomske analize in razvoj. Ljubljana 2000. Strmšnik, Igor. Slovenija v Evropi regij. 1997. Delovni zvezek.

Urad Republike Slovenije za makroekonomske analize in razvoj. Ljubljana 2002. Pečar, Janja.Regionalni vidiki razvoja Slovenije s poudarkom na finančnih rezultatih poslovanja gospodarskih družb v letu 2000. Delovni zvezek.

\section{THE STRATEGY OF REGIONAL DEVELOPMENT IN SLOVENIA}

\section{Summary}

The accession process of Slovenia to EU influenced the changes of regional policy in Slovenia with the promotion of the principles like programming, partnership, additionality and subsidiarity, which are the cornerstones of EU regional policy. The new Law on Balanced Regional Development was passed in July 1999 and lays down the general framework for the implementation of regional structural policy, conditions for financial incentives and the criteria for area designation. It aims to align the policy's objectives, instruments and institutional structures with those of the EU. Overall, the aim of regional policy in Slovenia is now specified as the reduction of regional disparities and the provision of balanced development throughout the country. The law determined preparation of the Strategy of regional development as a basis for future policy and implementation of new instruments.

In the same time Slovenia prepared the Strategy of Economic Development of Slovenia (SEDS) which presented the basic planning document in the new paradigm of programming documents defined by the Law on Public Finance. All strategic documents for different sectors should derive from the SEDS, that would became operational with the preparation of National Development Plan. Therefore the strategy of regional development was drafted as a stage towards the formation of a new legal basis for Slovenian regional policy. Its aim was to promote a shift away from the previously sectoral orientation of economic development and raise awareness of regional-based policies. The strategy proposed change in a number of important areas, some of which were subsequently addressed by the new Law on Balanced Regional Development. These included the improved coordination of policies with spatial impacts, the creation of a National Regional Development Council and Regional Development Agencies and greater transparency in the state incentive system. Sectoral interests more than regional concerns have tended to dominate 
budgetary spending and economic development. Co-operation between national government Ministries has improved, partly as a result of external intervention from the European Commission and renewed requirement to work together in fields such as regional policy.

Main targets of regional policy are focused to decrease the disparities among Slovenian regions in terms of economic development and living conditions, with development of regional urban centres in close co-operation with the countryside, prevention of emergence of new areas with development problems, preservation of the settlement pattern with special target to border and mountainous regions.

The territory has been divided into twelve statistical regions, which have prepared regional development programmes, co-financed by the state and municipal budgets which form the basis for financing of development projects of individual regions out of the State budget. The network of regional development agencies has been established which took care and co-ordinated the preparation of regional development programes, and is also responsible for their monitoring and assistance in preparation of individual projects, as for the promotion of the regional potencials.

Regional development is also one of the priorities of recently adopted National Development Plan 2001-2006, which provides promotion of entrepreneurship and development of competitiveness of economy as the main priority, followed by knowledge and human resources development as the second priority, development of information society and economic infrastructure as the third priority, restructuring of agriculture and development of rural areas as fourth, and last but not least the promotion of balanced regional development. 